PNL-7195

UC-630

\title{
Comparative Review of U.S. Department of Energy CERCLA Federal Facility Agreements
}

December 1989

Prepared for

The Environmental Compliance Division

Office of Environmental, Safety, and Health

U.S. Department of Energy

under Contract DE-AC06-76RLO 1830

Pacific Northwest Laboratory Operated for the U.S. Department of Energy

by Battelle Memorial Institute 


\section{DISClaimer}

This program was prepared as an account of work sponsored by an agency of the United States Government. Neither the United States Government nor any agency thereof, nor Battelle Memorial Institute, nor any of their employees, makes any warranty, express or implied, or assumes any legal liability or responsibility for the accuracy, completeness, or usefuliness of any information, apparatus, product, or process disclosed, or represents that its use would not infringe privately owned rights. Reference herein to any specific commerical product, process, or service by trade name, trademark, manufacturer, or otherwise, does not necessarily constitute or imply its endorsement, recommendation, or favoring by the United States Government or any agency thereof, or Battelle Memorial Institute. The views and opinions of authors expressed herein do not necessarily state or reflect those of the United States Government or any agency thereof.

\section{PACIFIC NORTHWEST LABORATORY operated by BATTELLE MEMORIAL INSTITUTE for the \\ UNITED STATES DEPARTMENT OF ENERGY under Contract DE-ACO6-76RLO 1830}

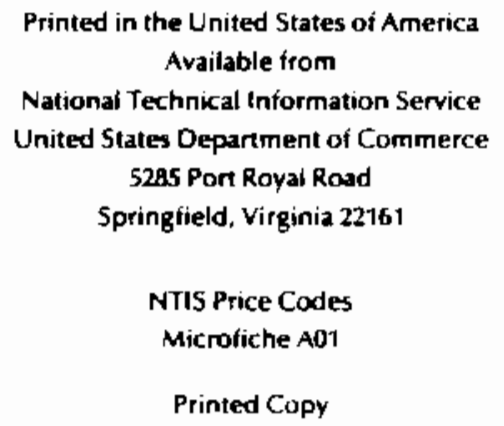

$\begin{array}{cc}\text { Pages } & \begin{array}{c}\text { Price } \\ \text { Codes } \\ 001-025\end{array} \\ 026-050 & \text { A02 } \\ 051-075 & \text { A03 } \\ 076-100 & \text { A04 } \\ 101-125 & \text { A05 } \\ 126-150 & \text { A06 } \\ 151-175 & \text { A07 } \\ 176-200 & \text { A06 } \\ 201-225 & \text { A09 } \\ 226-250 & \text { A10 } \\ 251-275 & \text { A11 } \\ 276-300 & \text { A12 } \\ & \text { A13 }\end{array}$


PNL -7195

UC -630

COMPARATIVE REVIEW OF

U.S. DEPARTMENT OF ENERGY CERCLA

FEDERAL FACILITY AGREEMENTS

\author{
M.R. Siegel \\ R.E. Gephart \\ P.L. Hendrickson \\ J.F. Keller \\ W.K. Waller
}

December 1989

Prepared for

The Environmental Compliance Division

Office of Environment, Safety, and Heaith U.S. Department of Energy

under Contract DE-ACO6-76RLO 1830

Pacific Northwest Laboratory

Richland, Washington 99352 



\section{EXECUTIVE SUMMARY}

This report consists of a comparison of the three signed Federal Facility Agreements (FFAS) entered into at this time by the U.S. Department of Energy (DOE) and the Model Provisions agreed to by DOE and the U.S. Environmental Protection Agency (EPA). The three site-specific FFAs reviewed were for the Lawrence Livermore National Laboratory (LLNL), Monticello Vicinity Properties and Millsite (Monticello), and the Hanford site. While the three FFAs are generally similar in format and in many provisions, they contain differences which are generally directly related to site-specific circumstances. For example, the three site-specific FFAs reflect varying levels of state authority and participation in the overall process. Generally, at LLNL, the State of California participates equally with EPA in the review of documents and consultations with DOE but EPA retains final authority regarding selection of remedial actions. Because the state does not have RCRA authorization, issues related to RCRA/CERCLA integration were less complex to resolve. Because Monticello does not include facilities or waste units subject to RCRA, that FFA defines the state's role in participation and consultation only under CERCLA section 120. The provisions in the Hanford FFA regarding coordination and the states' role are the most detailed, reflecting the complexity of the site and $f u l l$ integration of RCRA and CERCLA activities. EPA and the state share lead regulatory agency status since the State of Washington has base RCRA authority and will be authorized for corrective actions.

Differences in the FFAs in some cases may also reflect the progressive "refinement" of issues from DOE Headquarters perspective. For instance, all three FFAs contain provisions for the recovery of the states' costs related to implementation of the agreements. However, the language in these provisions differs primarily due to OOE Headquarters experience and progress toward defining, from a policy standpoint, how state costs would be paid. In addition, other sections, such as those dealing with jurisdictional issues and reservation of rights, have been refined with each subsequent agreement as DOE Headquarters more clearly defined preferred legal language which could be used in future agreements. 
These and other differences reflect the varied complexities of the sites, the agreements, and the issues. This report does not include an analysis of the differences but rather it provides factual comparisons.

The principal purpose of this report is to serve as a guide to those preparing FFAs for other DOE facilities or for those responsible for reviewing those FFAs. By comparing among the LLNL, Monticello, and Hanford FFAs, this report also provides information for future work to explain the rationale and background for the differences in these agreements. 


\section{ACKNOWLEDGEMENTS}

The authors would like to acknowledge the contributions of Connie Norton and Darby Stapp of Pacific Northwest Laboratory, (a) and Richard Hames, Richard Elliott, and Jeff Belfiglio of the law firm of Davis, Wright and Jones to the preparation of this report.

(a) Pacific Northwest Laboratory is operated for the U.S. Department of Energy by Battelle Memorial Institute under Contract DE-ACO6-76RLO 1830. 


\section{.}




\section{ACRONYMS}

AEA - Atomic Energy Act

ARAR - Applicable or Relevant and Appropriate Requirement

ATSDR - Agency for Toxic Substances and Disease Registry

CER:LA - Comprehensive Environmental Response, Compensation, and Liability Act CRP - Community Relations Plan

DOE - Department of Energy

EFA - Environmental Protection Agency

FFA - Federal Facility Agreement

LL.N_ - Lawrence Livermore National Laboratory

NCP - National Contingency Plan

RCRA - Resource Conservation and Recovery Act

RI/FS - Remedial Investigation/Feasibility Study

ROD - Record of Decision

TSD - Treatment, Storage, or Disposal unit 



\section{CONTENTS}

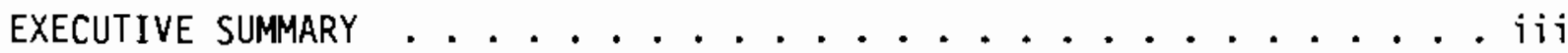

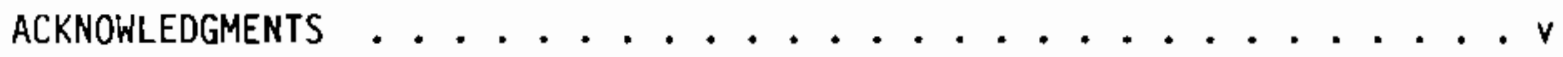

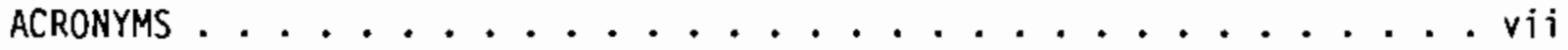
1.0 INTRODUCTION . . . . . . . . . . . . . . . . . . 1.1 1.1 PURPOSE . . . . . . . . . . . . . . . 1.1

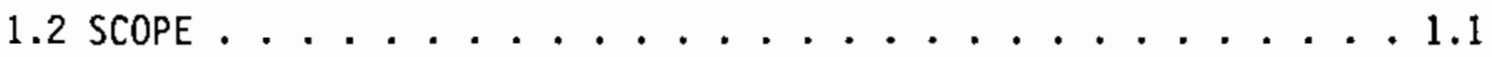
1.3 STATUTORY REQUIREMENTS . . . . . . . . . . . . . 1.2 1.4 BACKGROUND . . . . . . . . . . . . . . . . 1.2

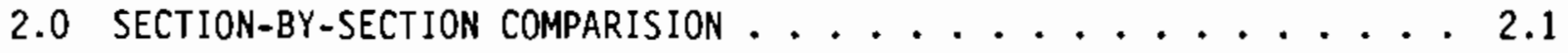
2.1 JURISDICTION . . . . . . . . . . . . . . 2.1 2.2 STATEMENT OF PURPOSE . . . . . . . . . . . 2.2 2.3 RCRA-CERCLA INTERGRATION; ROLE OF STATE . . . . . . 2.3

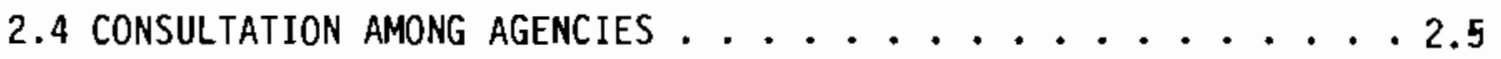

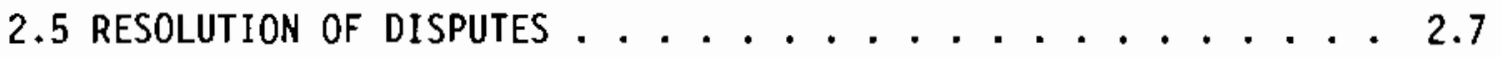
2.6 STIPULATED FACTS AND DETERMINATIONS . . . . . . . . 2.8 2.7 PERMITS . . . . . . . . . . . . . . . 2.9 2.8 QUALITY ASSURANCE AND SAMPLING AVAILABILITY . . . . . 2.9

2.9 PUBLIC PARTICIPATION/ADMINISTRATIVE RECORDS . . . . . . . 2.10

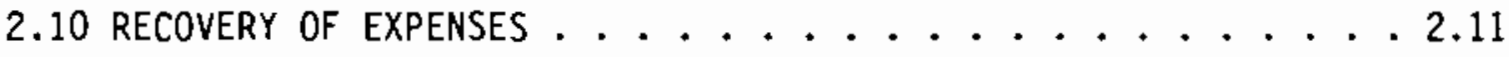
2.11 FUNDING . . . . . . . . . . . . . . 2.12

2.12 FORCE MAJEURE . . . . . . . . . . . . . . 2.13

2.13 COVENANT NOT TO SUE/RESERVATION OF RIGHTS . . . . . . 2.13

2.14 PROPERTY TRANSFER . . . . . . . . . . . . . 2.14

2.15 StIPULATED PENALTIES . . . . . . . . . . . 2.16

2.16 ENFORCEABILITY . . . . . . . . . . . . 2.16 


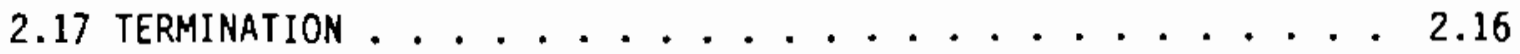

2.18 CONFIDENTIALITY . . . . . . . . . . . . . 2.17

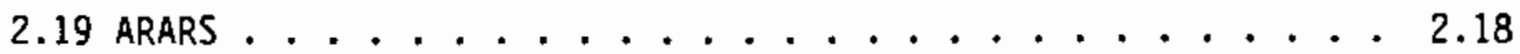

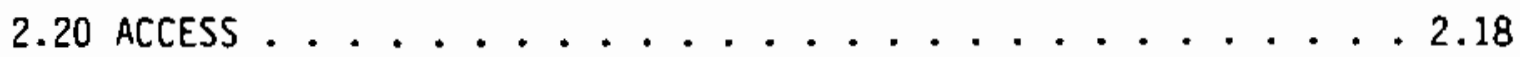

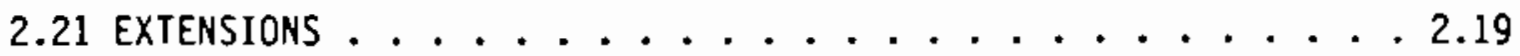

2.22 PROGRESS REPORTS . . . . . . . . . . . . . 2.20

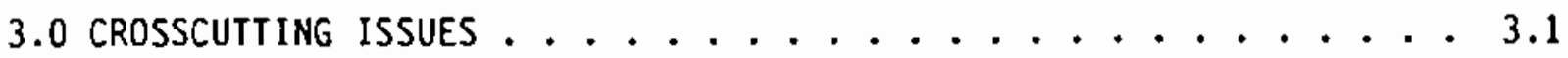

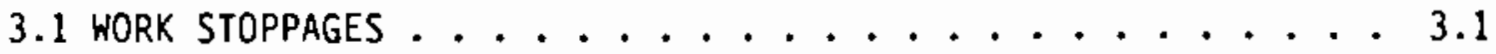

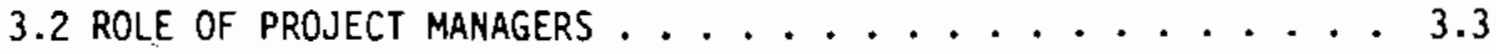

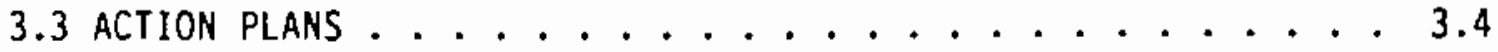

3.4 INCONSISTENCY WITH ATOMIC ENERGY ACT . . . . . . . . . 3.6

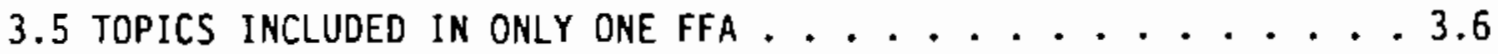

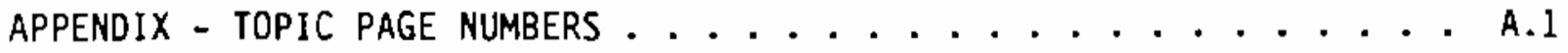




\section{TABLES}

2.1 COMPARISON OF FEOERAL FACILITY AGREEMENT STATEMENT OF PURPOSES. . . . 2.2

2.2 RCRA/CERCLA INTEGRATION. . . . . . . . . . . . . . . . . . . . . .

2.3 DOCUMENT ClASSIFICATION . . . . . . . . . . . . . . . . . . . . . . . .

2.4 CONSULTATION WITH EPA AND DOCUMENT REVIEW. . . . . . . . . . . . . . 2.7

2.5 DISPUTE RESOLUTION. . . . . . . . . . . . . . . . . . . . . . . .

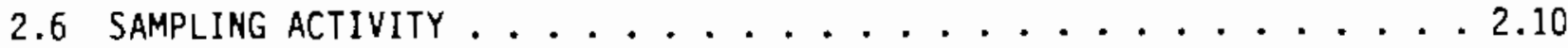

2.7 RECOVERY OF EXPENSES . . . . . . . . . . . . . . . . . . . . . . . . . .

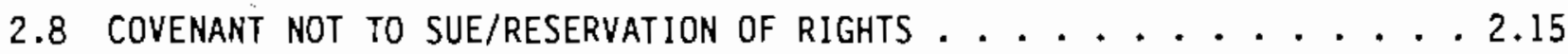

2.9 TERMINATION . . . . . . . . . . . . . . . . . 2.17

2.10 ACCESS TO PROPERTY . . . . . . . . . . . . . . . . . . . . . . . . .

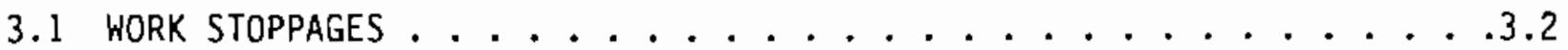

3.2 ROLE OF PROJECT MANAGERS . . . . . . . . . . . . . . . . . . . . . . 3

3.3 ACTION PLANS . . . . . . . . . . . . . . . . . . . . . . . . . . . 


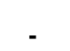




\subsection{INTRODUCTION}

\subsection{PURPOSE}

The purpose of this report is to present a comparison of the three fFAs executed by DOE and EPA. The report is intended to serve as a convenient reference guide for those responsible for drafting or reviewing future FFAs being considered by DOE. In addition, this report can provide the framework for the future analysis of completed FFAs and aid in the assessment of the relative merits of approaches and provisions used for different sites.

\subsection{SCOPE}

This report reviews the similarities and differences among the three existing FFAs (LLNL, Monticello, and Hanford). While similarities are discussed, the report focuses on differences which indicate varied approaches in each FFA. The report does capture the differences which may prove to be of importance or of interest with respect to drafting FFAs in the future for other DOE facilities.

No effort is made to assess the importance or impact of the similarities and differences among the three site-specific FFAs and the Model Provisions. It $s$ recognized that the differences are expected and are the result of the varied nature of the sites involved and differing scopes of the agreements due to different site-specific preferences for addressing the interface of CERCLA and RCRA requirements at these sites. Since the purpose of this report is to present only a comparison of the FFA provisions, little effort was made to present the reasons for the differences. This may be necessary as part of future work to analyze the policy implications of the different FFA provisions. It is clear, however, that many of the differences reflect the development of concepts and ideas from one FFA to the next.

To the extent possible, this report is presented as a section-by-section review of the provisions of each FFA. The section headings in this report generally conform to the articles common in each FFA. Accordingly, similarly titled articies found in each FFA are compared in this manner in Chapter 2. 
There are also several issues which are discussed under a number of different articles in the FFAs. These crosscutting issues, such as the responsibilities of project managers and work stoppages, are reviewed in Chapter 3.

Each section of Chapters 2 and 3 of this report begins with a listing of the relevant article and page number from each FFA. Appendix $A$ also lists the locations of comparative articles in each FFA.

\subsection{STATUTORY REQUIREMENTS}

Section 120(e) of the Comprehensive Environmental Response, Compensation, and Liability Act (CERCLA) requires that federal agencies responsible for specific hazardous waste sites enter into an interagency agreement with EPA regarding the clean-up activities at those sites. CERCLA requires that these agreements, also known as federal facility agreements, include 1) a review of alternative remedial actions and final remedy selection, 2) a schedule for the completion of each action, and 3) arrangements for the long-term operation and maintenance of the facility. As a general policy, DOE, DOD, and EPA are attempting to enter into these FFAs at a point earlier in the Superfund process than anticipated by Section 120(e) of CERCLA. Section 120(e) states that the head of the appropriate department, agency, or instrumentality shall enter into an interagency agreement within 180 days after the remedial investigation/feasibility study (RI/FS) is completed. The FFAs reviewed here involve agreements entered into within the planning and pre-remedial phase of the CERCLA process. Accordingly, the FFAs reviewed for this report include more detailed provisions for the preparation of RI/FSs, but include only general provisions regarding remedial design and remedial action comitments.

\subsection{BACKGROUND}

This section provides information regarding the timing of the completion of the FFAs reviewed for this report. The ten Model Provisions agreed to by EPA and DOE were transmitted to the DOE operations offices on May 31, 1988. The Model Provisions present a legal/policy framework for agreements between DOE and EPA at each site. The anticipated state role was not described in the Model Provisions in order to allow each state the flexibility to define 
its preferred level of participation. The LLNL FFA was finalized November 2, 1988. The parties to the agreement are DOE, EPA, the California Department of Health, and the California Regional Water Quality Control Board. The Monticello FFA was finalized December 19, 1988. The parties to this agreement are DOE, EPA, and the Utah Department of Health. The Hanford FFA was finalized in May, 1989. The parties to this agreement are DOE, EPA, and the Washington Department of Ecology (Ecology).

The LLNL FFA includes a legal agreement and attachments which provide a general outline for actions and timetables at the site. The Monticello FFA includes a work plan as well as several attachments. The Hanford FFA includes both a legal agreement and a detailed action plan. 


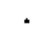




\subsection{SECTION-BY-SECTION COMPARISON}

This chapter presents a detailed comparison of provisions comnon among the FFAs. To the extent possible, the topic headings in this chapter closely parallel those found in the FFAs. This was not always possible, however, because of slight variations in the wording of the article headings in each FFA. Each topic begins with a listing of the relevant section and page number in each FFA. Topics noted with an asterisk indicate that model language is available. In addition, it should be noted that many of the differences in various section represent growth and development of the language as each subsequent FFA was negotiated.

\subsection{JURISDICTION*}

$\begin{array}{ll}\text { LLNL: } & \text { Art. I, pp. 1-3 } \\ \text { Monticel lo: } & \text { Art. I, pp. 1-3 } \\ \text { Hanford: } & \text { Art. I, pp. 3-6 }\end{array}$

The LLNL FFA generally is similar to the Model Provision. It also includes a jurisdiction provision for the California Department of Health Serices and the California Regional Water Quality Board. Under a second provision, DOE commits to take all necessary actions to effectuate the agreement.

The Monticello agreement is also similar to the Model Provision with two exceptions. First, there are no references to RCRA in the Monticello agreement. Second, a jurisdiction provision is included for the Utah Department of Health.

The Hanford agreement differs from the Model Provision in several areas. Considerable attention is devoted to the jurisdiction of the Ecology. A provision is included on the placement of Hanford on the National Priorities List (NPL). DOE acknowledges that it is bound by the agreement and that the terms of the agreement may be enforced against DOE. Finally, a provision on RCRA treatment, storage, and disposal (TSD) units is inciuded. 


\subsection{STATEMENT OF PURPOSE*}

LLNL: Monticello:

Hanford:
Art. III, pp. 6-8

Art. II, pp. 3-6

Art. III, pp. 7-9

The purpose sections of the three FFAs differ in several respects from the Model Provision. All three agreements include the Model Provision language on identifying the nature, objective, and schedule of response actions, and the provision on implementing the selected remedial and final actions in accordance with CERCLA. A provision on establishing requirements for the performance of Remedial Investigation/Feasibility Studies (RI/FS) is also included in each agreement. Table 2.1 presents a comparison of this section in the FFAs.

TABLE 2.1. Comparison of Federal Facility Agreement Statement of Purposes

\section{OBJECTIVE}

Identify TSD Units Requiring Permits; Establish Compliance Schedules

Identify Interim Action Alternatives Needed Prior to Final Remediation

Establish Requirements for Performance of Investigations Identify Nature, Objective, and Schedule of Response Actions

Implement Selected Remedial and Final Actions in Accord with CERCLA

Implement Selected Corrective Actions in Accord with RCRA

\section{$\underline{\text { LLNL MONTICELLO HANFORD }}$ MODEL}

No

No

Yes

No

No

Yes

Yes

Yes

Yes

Yes

Yes

Yes

Yes

Yes

Yes

Yes

Yes

Yes

Yes

Yes

No

No

Yes

No 


\subsection{RCRA-CERLCA INTEGRATION; ROLE OF STATE*}

LLNL:

Monticello:

Hanford:
Art. VII, XIV, pp. $16-18,38$

Art. VIII, IX, pp. 18-24

Art. XXII-XXVII (part 4), pp. 9-12, 47-53

The Hanford and LLNL both provide for integration of DOE's CERCLA response action obligations and RCRA corrective action obligations to avoid the imposition of conflicting responsibilities on DOE. (Monticello does not contain RCRA units). The Hanford FFA also includes requirements for RCRA past practices and TSD units. However, the three FFAs take varying approaches to the states' authority and role in the overall process, depending upon the scope of the agreement (see Table 2.2).

TABLE 2.2. RCRA/CERCLA Integration

Site includes

RCRA TSD Units

Agreement includes

RCRF. compliance

in its purpose article

Intention to integrate CERCLA and RCRA activities

Agreement specifically addresses RCRA permitting

Separate CERCLA and RCRA actions contemplated

State given lead regulatory role for certain response or corrective actions

EPA given ultimate authority regarding remedy selection

EPA s selection of CERCLA remedy subject to dispute resolution

Separate dispute resolution for EPAstate disputes
LLNL MONTICELLO HANFORD MODEL

Yes

No

Yes

NA

Yes

NA

Yes

Yes

Yes

NA

Yes

Yes

No

NA

Yes

No

No

NA

Yes

No

No

NA

Yes

No

Yes

Yes

Yes

Yes

No

No

No

No

No

No

Yes

No 
The LLNL FFA follows the Model Provision for RCRA/CERCLA coordination. Generally, the state participates equally with EPA in the review of documents and consultations with DOE, but EPA retains final authority regarding selection of remedial actions. Although LLNL's Article VII states that the agreement is intended to satisfy both RCRA and CERCLA, the process established by Article VIII (Scope of Agreement) is based on CERCLA. In contrast to the Hanford FFA, there is no provision in the LLNL FFA for the state to be lead regulatory agency, nor is there mention of any lead state role with respect to TSD permitting and closure requirements because this agreement does not include RCRA activities other than corrective action.

The Monticello FFA omits comparable provisions on integration of RCRA and CERCLA. Unlike Hanford and LLNL, Monticello does not involve facilities or waste units subject to RCRA authority. Thus, the agreement only addresses the state's role in participation and consultation under CERCLA $\S 120$. Like LLNL, the Monticello agreement does not provide for the state to share lead regulatory agency status with EPA. Monticello Article VIII (Role of State Government) incorporates a Superfund Memorandum of Agreement which allows the state to share oversight responsibilities with EPA, but designates EPA as "lead agency with ultimate responsibility and authority."

The provisions in the Hanford FFA regarding coordination and the state's role are the most detailed, reflecting the complexity of the site. The Hanford FFA's Article IV expands significantly on the Model Provision's RCRA/CERCLA coordination language by specifically addressing TSD groundwater contamination and the division of RCRA authority between EPA and Ecology. Unlike the other two FFAs, the Hanford FFA divides the site into TSD units, subject to the state's RCRA authority, and past-practice units, subject either to CERCLA response action or to RCRA corrective action. The Hanford agreement is also unique in providing a series of articles (Part 4) that integrate EPA and state responsibilities, including a special dispute resolution procedure for resolving jurisdictional and other disputes between EPA and Ecology. The Hanford FFA recognizes the state's lead role in permitting and closure of TSD facilities, and provision is made for the state to assume lead regulatory agency status at certain operable units (groupings of past-practice units). Designation of lead regulatory status is accomplished through the action plan. A specific 
provision is included in the Hanford agreement for avoidance of physically inconsistent actions imposed by EPA and the state. Neither the LLNL nor the Monticello FFA have comparable provisions.

\subsection{CONSULTATION AMONG AGENCIES*}

LLNL: Monticel10: Hanford:
Art. IX, pp. $21-29$

Art. XII, pp. 27-38

Art. XIV, pp. 34-35, Action Plan, Sec. 9

Each of the site-specific FFAs defines various documents as either primary or secondary documents for purposes of review by the parties to the agreements. Table 2.3 sets forth the classification of documents by each FFA. In general, the FFAs require that primary documents be reviewed and approved by the parties to the agreement. Primary documents are subject to dispute resolution. Secondary documents are subject to review and comment by the parties, but are not subject to dispute resolution. The identification of primary and secondary documents differs among the FFAs.

Table 2.4 presents additional information concerning DOE and state consultation with EPA.

TABLE 2.3. Document Classification

\begin{tabular}{|c|c|c|c|c|}
\hline Scope of Work & 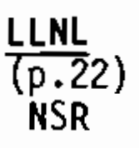 & $\frac{\text { MONTICELLO }}{(\mathrm{p} .30)}$ & $\begin{array}{l}\frac{\text { HANFORD }}{(\mathrm{P} .9-2} \text { AP) } \\
S\end{array}$ & $\frac{M O D E L}{(P .9)}$ \\
\hline RI/FS Work Plan & $\mathbf{P}$ & $P$ & $P$ & $\mathbf{P}$ \\
\hline $\begin{array}{l}\text { Initial Remedial } \\
\text { Action/Data } \\
\text { Quality } \\
\text { Objectives }\end{array}$ & NSR & $\mathrm{S}$ & $\mathrm{s}$ & $\mathrm{S}$ \\
\hline $\begin{array}{l}\text { Quality } \\
\text { Assurance } \\
\text { Project Plan }\end{array}$ & P & NSR (a) & NSR (a) & NSR (a) \\
\hline $\begin{array}{l}\text { Sampling and } \\
\text { Data Results }\end{array}$ & NSR & $\mathrm{S}$ & $\mathrm{s}$ & $\mathrm{S}$ \\
\hline Risk Assessment & $\mathrm{S}$ & $P$ & $\mathrm{~S}$ & $P$ \\
\hline
\end{tabular}


TABLE 2.3. Document Classification (condt)

$\frac{\text { LLNL }}{(p .22)} \quad \frac{\text { MONTICELLO }}{(p .30)} \quad \frac{\text { HANFORD }}{(p .9-12}$ AP) $\frac{\text { MODEL }}{(p .9)}$

\begin{tabular}{|c|c|c|c|c|}
\hline RI Report & $\mathbf{P}$ & $\mathbf{P}$ & $\begin{array}{l}\text { Phase I - S } \\
\text { Phase II - P }\end{array}$ & $\mathbf{P}$ \\
\hline $\begin{array}{l}\text { Site } \\
\text { Characteriz- } \\
\text { ation Sumnary }\end{array}$ & NSR & $\mathrm{s}$ & S & NSR \\
\hline $\begin{array}{l}\text { Initial } \\
\text { Screening of } \\
\text { Alternatives }\end{array}$ & NSR & $\mathrm{P}$ & S & $\mathrm{p}$ \\
\hline $\begin{array}{l}\text { Detailed } \\
\text { Analysis of } \\
\text { Alternatives }\end{array}$ & NSR & $\mathrm{s}$ & $\mathrm{s}$ & $\mathrm{s}$ \\
\hline $\begin{array}{l}\text { Treatability } \\
\text { Studies }\end{array}$ & $\mathrm{s}$ & $\mathrm{S}$ & $s(b)$ & s \\
\hline $\begin{array}{l}\text { Community } \\
\text { Relations Plan }\end{array}$ & $\mathrm{P}$ & P & NSR (c) & NSR \\
\hline FS Reports & $P$ & $\mathrm{P}$ & $\mathbf{P}$ & $\mathbf{P}$ \\
\hline Proposed Plan & $P(d)$ & $P$ & $P$ & $P$ \\
\hline $\begin{array}{l}\text { Record of } \\
\text { Decision }\end{array}$ & $P$ & $P$ & NSR & $P$ \\
\hline Remedial Design & $\mathbf{P}$ & $P$ & $\mathrm{P}$ & $\mathrm{P}$ \\
\hline $\begin{array}{l}\text { Remedial Action } \\
\text { Work Plan }\end{array}$ & $\mathrm{P}(\mathrm{e})$ & $\mathrm{P}$ & $\mathbf{P}$ & $\mathbf{P}$ \\
\hline
\end{tabular}

(a) Included as part of RI/FS Work Plan.

(b) Treatability study work plan can be established as primary document by lead regulatory agency.

(c) Community relations plan is a joint DOE, EPA, and state document.

(d) Called Proposed Remedial Action Plan.

(e) Called Remedial Action Implementation Plan.

P - Primary document

$S$ - Secondary document

NSR - Not specifically referenced

AP - Action plan 
TABLE 2.4. Consultation with EPA and Document Review

\begin{tabular}{|c|c|c|c|c|}
\hline & $\frac{\operatorname{LLNL}}{(p \cdot 21)}$ & $\frac{\text { MONT ICELLO }}{(p \cdot 27)}$ & $\frac{\text { HANFORD }}{(\bar{p} \cdot 9-1, \text { AP) }}$ & $\frac{\text { MODEL }}{(p \cdot 7)}$ \\
\hline $\begin{array}{l}\text { Meeting of } \\
\text { project managers }\end{array}$ & quarterly & quarterly & quarterly (a) & every 30 days \\
\hline $\begin{array}{l}\text { Time period } \\
\text { for review of } \\
\text { draft documents }\end{array}$ & 60 days & 60 days & 45 days (b) & 30 days \\
\hline $\begin{array}{l}\text { Time period } \\
\text { for DOE to } \\
\text { respond to } \\
\text { comments }\end{array}$ & 60 days & 60 days & $\begin{array}{l}30 \text { days } \\
\text { (respond on ly) } \\
45 \text { days (update } \\
\text { document) (b) }\end{array}$ & 30 days \\
\hline $\begin{array}{l}\text { Time period } \\
\text { for DOE to } \\
\text { make changes } \\
\text { in response } \\
\text { to dispute } \\
\text { resolution }\end{array}$ & 35 days & 35 days $(c)$ & 21 days & 35 days (c) \\
\hline
\end{tabular}

(a) Unit managers meet monthly.

(b) 60 days for RI/FS work plans, RCRA work plans and closure plans.

(c) This time period differs from time period set forth in the dispute resolution section to incorporate dispute resolution decisions.

\subsection{RESOLUTION OF DISPUTES*}

LLNL: $\quad$ Art. $X, p p .29-34$

Monticello: Art. XIV, Pp. 41-46

Hanford: Art. VIII, XV, XXV, pp. 21-24, 35-39, 49-51

The LLNL, Monticello, and Hanford (procedure outlined in Part 3, Art.

XV) FFAs provide for the same general process for dispute resolution, starting with informal dispute resolution and moving to a Dispute Resolution Committee (DRC), Senior Executive Committee (SEC), the EPA Regional Administrator, and ultimately the EPA Administrator.

The Hanford FFA outlines separate dispute resolution procedures for disputes between the State and DOE concerning the RCRA permitting/closure of TSO facilities (Part 2, Art. VIII), and between EPA and the State pertaining to the integration of their respective CERCLA and RCRA responsibilities (Part 4, Art. XXV). Table 2.5 sets forth a comparison of dispute resolution provisions. 
IABLE 2.5. Dispute Resolution

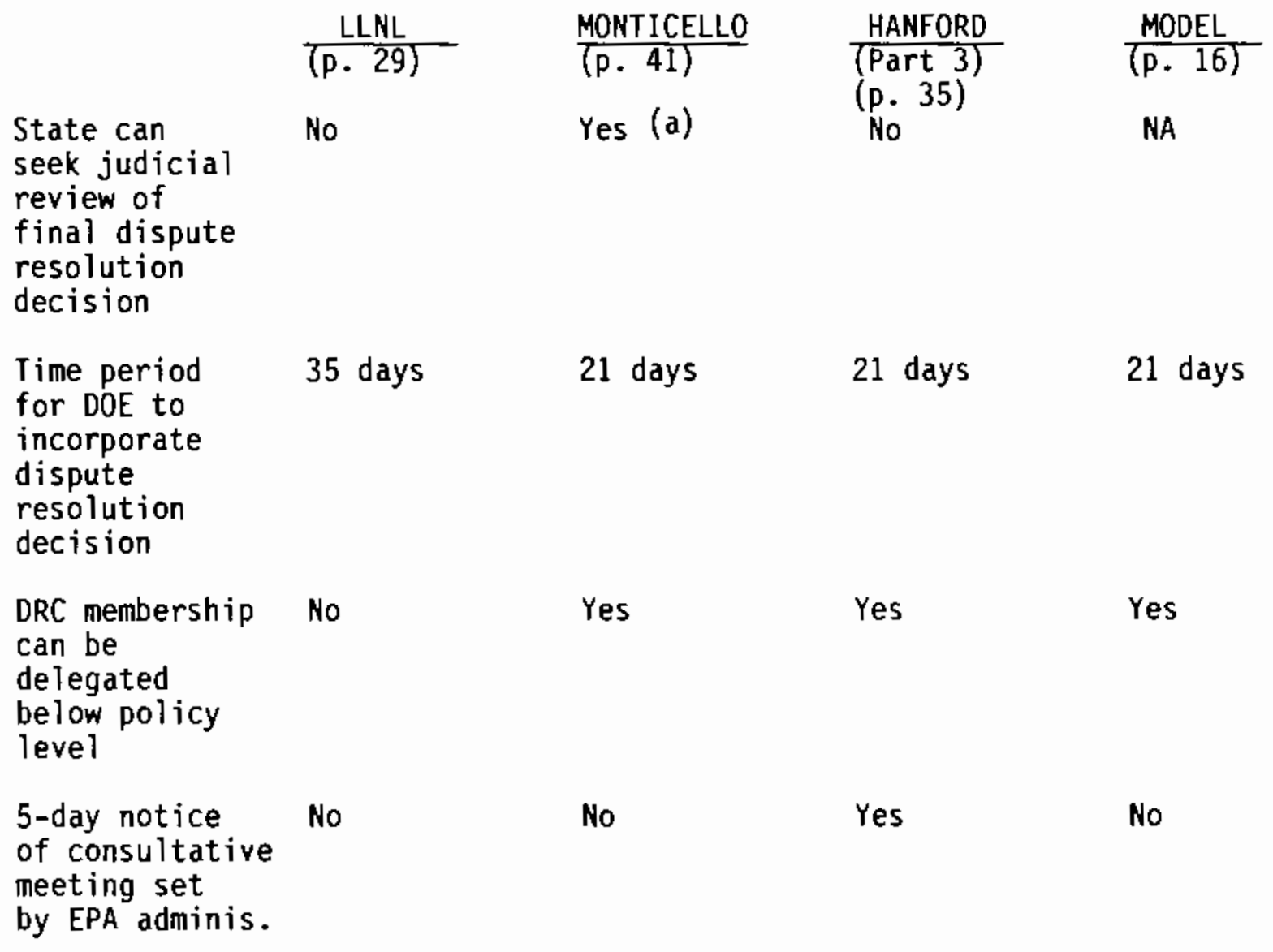

(a) References section of FFA concerning reservation of rights by the state.

\subsection{STIPULATED FACTS AND DETERMINATIONS}

LLNL: Art. IV-V, pp. 8-16

Monticello: Art. V-VII, Pp. 12-18

Hanford: Art. VI, XII, PP. 17-19, 26-29

The three site-specific FFAs differ from each other in their treatment of stipulated facts and determinations. Under the LLNL FFA, none of the stipulated facts or stipulated determinations are to be considered admissions by any party with respect to any unrelated claims by a party or any claims by persons not a party to the agreement. In the Monticello FFA, all parties agree on the statement of facts, but there are no references to admissions. However, Amendment 1 of the Monticello FFA states that nothing in the agreement is an admission with respect to any claim by a non-party. The conclusions of law 
and statement of determinations were agreed to by EPA and the state only. In the Hanford agreement, the findings and determinations are made by EPA and Ecology only. They are not to be considered admissions and their use is restricted to the agreement. The substantive provisions in the stipulated facts and determinations also differ considerably between the three agreements.

\subsection{PERMITS}

LLNL: Art. XII, pp. 35-37

Monticello: None

Hanford: Art. XVII, pp. 40-42

The Hanford FFA recognizes that permits for CERCLA cleanup activities conducted onsite are not required, but that activities must meet the applicable or appropriate and relevant requirements (ARARs). DOE agrees to provide an explanation of how its actions will meet the ARARs. DOE is not relieved of obtaining any permits required for offsite activities. The Hanford FFA includes a procedure for modifications to the agreement if DOE is unable to obtain a permit for offsite activities which is consistent with the agreement. The LLNL agreement has similar provisions to the Hanford agreement. The Monticello agreement does not contain a section on permit acquisition.

\subsection{QUALITY ASSURANCE AND SAMPLING AVAILABILITY}

LLNL: $\quad$ Art. XIX, XX, Pp. 53-55

Monticello: Art. XVII, $p, 41$

Hanford: Art. $X X X, X X X Y, P p .57,60$

The procedures identified in this portion of the site-specific FFAs are similar in that all require quality assured data to be submitted. However, there are differences in regards to when required data is to be submitted and when notification of prior sampling activity is to be made. A comparison of these provisions is found in Table 2.6.

The LLNL FFA does not reference any development of quality assurance procedures. The Hanford and Monticello FFAs, however, specifically require DOE to develop quality assurance plans in accordance with EPA guidance. 
TABLE 2.6. Sampling ACtivity

LLNL MONTICELLO HANFORD MODEL

Notification by DOE

to EPA/state of any

monitoring activity

No

Yes

(30 days)

(48 hours)

Yes No

Time period for DOE

to submit quality

data from time of

collection

DOE required to allow

EPA/state to observe

field work

DOE to allow split/

duplicate samples by

$\mathrm{EPA} / \mathrm{state}$

$2 / 1,5 / 1$

$8 / 1,11 / 1$

No

45 days

45 day

No

Yes

Yes

Yes

No

\subsection{PUBLIC PARTICIPATION/ADMINISTRATIVE RECORDS}

LLNL: $\quad$ Art. XXIII-XXIV, Pp. 47-49

Monticello: Art. XXXIV, Pp. 72-73

Hanford: Art. XLII, pp. 65-67

A11 three FFAs require that action taken under the agreements comply with CERCLA, the National Contingency Plan (NCP), and applicable EPA guidance.

The Hanford and Monticello FFAs specifically require DOE to develop and implement a community relations plan (CRP). The Hanford FFA further specifies that the CRP will comply with RCRA requirements. The LLNL agreement does not specifically spell out DOE's responsibility for developing a CRP.

The LLNL FFA contains a section requiring the parties to give a two-day advance notice prior to the issuance of a press release. A similar provision is contained in the Hanford action plan. The Monticello FFA contains a similar notice provision, but notice must be given for press releases as well as prior to "providing significant information to the media."

The Hanford action plan and Monticello work plan contain additional detailed requirements related to issues such as public meetings, mailing lists and newsletters, public comment opportunities, and technical assistance grants. 
All agreements specify that DOE is responsible for establishing and maintaining an administrative record consistent with EPA policy and guidance. However, there are differences among the agreements on the number and location of repositories.

\subsection{RECOVERY OF EXPENSES}

LLNL: $\quad$ Art. XXV, pp. 49-50

Monticello: Art. XXVII, pp. 61-63, Amendment No. 1, 3

Hanford: Art. XXVIII, pp. 54-55

All three site-specific FFAs contain provisions for the recovery of the states' costs related to implementation of the agreements, but there are few other similarities. States' CERCLA expenses are recovered through the DOE grant process. There are significant differences in caps, budgetary estimates, and dispute resolution procedures. These differences are summarized in Table 2.7. The remainder of this subsection will highlight several of those differences.

The Monticello FFA excepts cost disputes between DOE and the state from the dispute resolution process and covenant not to sue. Amendment 1 to the FFA clarifies that dispute resolution will be covered in the separate funding agreements contemplated by Art. XXVII(B)(2) and provides an interim procedure.

The Hanford FFA has no cap, but its annual grant is to be "consistent" with the state's estimated expenses. State costs actually incurred in excess of the grant are not DOE's responsibility.

Under the Hanford. FFA, disputes over CERCLA costs are resolved through DOE's financial assistance grant procedures (10 CFR Parts 600 and 1024). The LLNL FFA allows DOE to "challenge" the amount to be paid to the state. No mention is made in the LLNL agreement of dispute resolution in this area, although the dispute resolution provision generally applies to disputes arising under the agreement. An "unresolved challenge" is to be referred to federal district court.

The Hanford FFA divides recoverable state costs into three categories: permit fees and reasonable service charges, CERCLA costs, and environmental monitoring costs. CERCLA costs are explained above. DOE also agrees to pay the state's permit fees and service charges on the same basis as any other RCRA TSD operator. Disputes over such fees are under Article VIII Dispute Resolution (in which Ecology has final authority). There is a separate Mutual Cooperation Funding Agreement to cover off-site state environmental monitoring costs. 
TABLE 2.7. Recovery of Expenses

\begin{tabular}{|c|c|c|c|}
\hline & LLNL & MONT ICELLO & HANFORD \\
\hline $\begin{array}{l}\text { Cost of "implementing" } \\
\text { agreement covered }\end{array}$ & Yes & Yes & Yes \\
\hline $\begin{array}{l}\text { - Amount of cap } \\
\text { on implementation } \\
\text { expenses }\end{array}$ & $\begin{array}{l}\$ 325,000 \\
\text { total }\end{array}$ & $\begin{array}{l}\$ 600,000 \\
\text { (subject to } \\
\text { change) }\end{array}$ & $\begin{array}{l}\text { Amount of } \\
\text { annual grant } \\
\text { (CERCLA expenses) }\end{array}$ \\
\hline $\begin{array}{l}\text { - Prior estimate of } \\
\text { State's annual } \\
\text { cost required }\end{array}$ & No & Yes & Yes \\
\hline $\begin{array}{l}\text { - Dispute } \\
\text { resolution } \\
\text { procedure }\end{array}$ & $\begin{array}{l}\text { Court } \\
\text { (possibly } \\
\text { after dispute } \\
\text { res.) }\end{array}$ & $\begin{array}{l}\text { to be covered } \\
\text { in separate } \\
\text { agreement }\end{array}$ & $\begin{array}{l}\text { DOE grant } \\
\text { procedures }(10 \\
\text { CFR 600 \& 1024) }\end{array}$ \\
\hline $\begin{array}{l}\text { - Reservation of } \\
\text { other CERCLA } \\
\text { costs }\end{array}$ & No & Yes & No \\
\hline $\begin{array}{l}\text { RCRA permit fees } \\
\text { allowed }\end{array}$ & $N_{0}$ & No & Yes (a) \\
\hline $\begin{array}{l}\text { Off-site state } \\
\text { monitoring costs } \\
\text { covered }\end{array}$ & No & No & Yes \\
\hline
\end{tabular}

(a) As soon as state's permit fee system is in place, grant will no longer cover these.

\subsection{FUNDING*}

LLNL:

Monticello:

Hanford:
Art. XXVII, p. 52

Art. XXXVII, Pp. 75-76

Art. XLVII, pp. 74-76

The Monticello and LLNL agreements both contain language regarding funding similar to that contained in the Model Provision. DOE agrees to take all necessary steps to obtain timely funding of its obligations under these agreements. Each agreement specifies that any payment or obligation of funds is subject to the availability of appropriated funds and that the agreements should not be interpreted to require DOE to act in violation of the 
Anti-Deficiency Act. In each of these agreements, the states and EPA reserve the right to initiate action against DOE in the event that appropriate funds are not available to fulfill DOE's obligations under the agreements.

The Hanford FFA augments the Model Provision with some additional language. This FFA states that Ecology and EPA shall assist DOE in determining the funding levels required to support DOE's obligations under the agreement. The Hanford FFA also states that if appropriated funds are not available to fulfill DOE's obligations, the parties shall attempt to agree upon "appropriate adjustments" to the dates which require the payment or obligation of funds. From this point, DOE and the State essentially "agree to disagree." The provision states that DOE may raise as a defense that any failure or delay was caused by the unavailability of appropriated funds. Ecology explicitly disagrees that the lack of appropriations is a valid defense.

\subsection{FORCE MAJEURE}

LLNL: $\quad$ Art. XXIX, pp. 53-54

Monticello: Art. XXXIII, pp. 71-72

Hanford: Art. XLVII, pp. 72-74

The Hanford agreement adopts the Model Provision except for an additional clause stating that the state does not concede any presumption that certain events arise from causes beyond the control of a party to the agreement. In addition, Ecology reserves the right to withhold concurrence on time extensions based on a Force Majeure. The Monticello agreement adopts the Model Provision. The LLNL FFA adopts the Model Provision with the addition of EPA to the language regarding insufficiency of appropriated funds.

\subsection{COVENANT NOT TO SUE/RESERVATION OF RIGHTS}

LLNL: : Art. XXVI, XXXI, Pp. 51, 54-55

Monticel10: Art. XXXIV, XXIX, PP. 59, 63-65

Hanford: Art. XXVII, XLVI, pp. 52-53, 70-73

Al1 three site-specific FFAs contain covenants not to sue. The Hanford FFA is unique in extending its covenant not to sue to DOE's contractors.

With regard to reservation of rights, the Hanford FFA contains a reservation of independent state RCRA authority. If Ecology and EPA disagree 
over a site where both may have statutory jurisdiction, then the state reserves its right to act independently. In the event of such a dispute, both EPA and the state reserve their rights to impose directly their requirements on DOE and take any action that would be appropriate in the absence of the agreement. The Hanford FFA also allows EPA or the state to seek judicial review of the other's action on the ground that it conflicts with federal or state law. The Hanford FFA further allows EPA and the state to proceed against contractors for matters outside the agreement, and even for covered matters if DOE fails to comply.

The Monticello FFA adds a state reservation that references certain provisions of the agreement relating to recovery of expenses, enforceability and funding. However, the state agrees to exhaust dispute resolution procedures prior to enforcing these rights, with the exception of recovery of expenses.

Both the Monticello and LLNL FFAs reserve EPA's and the states' rights to take action in the event of previously undetected conditions. The Hanford agreenent has no comparable provision, although such authority could be implied under the reservation regarding new information, including information regarding releases. The Hanford FFA includes a reservation on the part of EPA and the state for abatement of an imminent and substantial endangerment, while Monticello and LLNL FFAs do not. The Hanford agreement also is unique in including an express reservation of $D O E^{\prime} s$ rights and defenses, in the event EPA or the state exercise the aforementioned authority. See Table 2.8 for a comparison of these provisions.

\subsection{PROPERTY TRANSFER}

$\begin{array}{ll}\text { LLNL: } & \text { Art. XXVII, pp. 55-56 } \\ \text { Monticel 10: } & \text { Art. XXII (b), p. 57 } \\ \text { Hanford: } & \text { Art. XLI, p. 66 }\end{array}$

The issues of property transfer and conveyance of title are addressed in all three site-specific FFAs, but are covered to a limited extent in the Monticel10 FFA under the Access section. The basic objective of the provisions in the Hanford and LLNL agreements is to assure continued maintenance of any containment, treatment, or monitoring system. The LLNL agreement references CERCLA section 120(h). 
TABLE 2.8. Covenant Not to Sue/Reservation of Rights

$$
\text { LLNL MONTICELLO HANFORD MODEL }
$$

EPA/state reserve

regarding new

information or

noncompliance

Yes

Yes

Yes

No

EPA/state reserve

regarding previously

undetected conditions

Yes

Yes

No

No

$E P A / s t a t e$ reserve

regarding natural

resources damages

Yes

Yes

Yes

No

EPA/state reserve

regarding imminent

and substantial

endangerment

No

No

Yes

No

State reserves

independent RCRA

authority

No

No

Yes

No

EPA and state

grant covenant

not to sue

Yes

Yes

Yes

Yes

DOE reserves

rights and defenses

No

No

Yes. No

Al) parties reserve

rights/defenses in

event of dispute

between EPA and state

No

No

Yes

No

No bar or release

of third parties

Yes

Yes

Yes

No

EPA/state reserve regarding work not

covered by agreement

Yes

Yes

Yes

No

EPA/state reserve

right to enforce

directly against

DOE contractors

No

No

Yes

No

State reserves right

to judicially

challenge remedial

action selection

Yes

Yes

Yes No

DOE reserves CERCLA

$\S 104$ removal

Yes

No

Yes

Yes 


\subsection{STIPULATED PENALTIES*}

LLNL:

Monticello:

Hanford:
Art. XXXIII, pp. $56-58$

Art. $X X X I, p p .66-68$

Art. XIX, pp. 43-45

The Monticello and LLNL FFAs adopt the Model Provision. The CERCLA stipulated penalties article in the Hanford agreement adopts the model language for CERCLA work only, with the added provision that Ecology may identify stipulated penalties to EPA for assessment.

\subsection{ENFORCEABILITY*}

LLNL: $\quad$ Art. XXIV, pp. 58-59

Monticel10: Art. $X X X, p p .65-66$

Hanford: Art. IX, XX, pp, 24-25, 45-46

The Monticello and LLNL FFAs adopt the Model Provision on enforceability. The Hanford agreement includes separate enforceability sections for the permitting/closure of TSD facilities (Art. IX) and for remedial and corrective actions (Art. $X X$ ). Article $X X$ of the Hanford FFA adopts the Model Provision for CERCLA activities. Article IX covers enforceability under RCRA and provides for enforcement actions by citizens and the State of Washington. The Hanford FFA also includes a letter from the U.S. Department of Justice recongnizing the State's enforcement authority.

\subsection{TERMINATION}

LLNL: Monticello: Hanford: Art. $X X X V, p .60$ Art. $X X X V I, p, 75$ Art. XLIII, pp. $67-68$

All three site-specific FFAs essentially provide that the agreements will terminate when DOE demonstrates that all the work required by the agreement and related action plan has been satisfactorily completed. The mechanics of termination vary somewhat among the agreements. None of the FFAs makes any specific provision for resolution of a dispute among the parties regarding whether DOE has satisfactorily met the conditions for termination. The Hanford FFA is unique in providing for a review by all parties five years from the date of execution, and every five years thereafter, with an option on the part of EPA and the state to withdraw from the agreement. See Table 2.9 for a comparison of the termination provisions. 
TABLE 2.9. Termination

LLNL MONTICELLO HANFORD

Termination occurs when DOE completes all work or all parties agree to termination

No

No

Yes

Termination occurs when DOE satisfies

all terms of agreement

Yes

Yes

No

Written notice of

satisfaction required

Yes

Yes

Yes (a)

Five-year CERCLA

remedial action

review required

Yes

Yes

Yes

Five-year compliance

review with EPA and

state option to

withdraw

No

No

Yes

(a) Notices of completion are required for each operable unit.

\subsection{CONFIDENTIALITY}

LLNL :

Monticel10:

Art. XVIII (D), p. 43

Hanford:

Art. $X X V I, p p .60-61$

Art. XLV, p. 69

All three site-specific FFAs protect classified information from public disclosure and reference the requirements of the Atomic Energy Act (AEA). The Hanford FFA is more specific and incorporates protections for unclassified controlled nuclear information, restricted data and national security information. The Hanford FFA differs by recognizing that DOE may not share certain information with EPA and the state, subject to EPA's and the state's right to obtain access in accordance with applicable law. The LLNL and Monticello agreements provide that classified information shall not be made available to the "public" but do not specifically cover access by the other parties. 
The LLNL and Monticello FFAs specify that records shall not be publicly disclosed which could otherwise be withheld pursuant to the Freedom of Information Act (FOIA) or the Privacy Act. Under the Monticello agreement, DOE may also assert a "confidentiality" claim as to information required by the agreement. EPA then determines whether the information is confidential, and any dispute is resolved under EPA's public information regulations (40 CFR Part 2). Likewise, DOE may claim "confidentiality" under state law, which claim is determined by the state.

The Hanford FFA makes no mention of either FOIA or the Privacy Act. However, the agreement allows a party to assert, on its own behalf or on behalf of a contractor or consultant, a "business confidentiality" claim or privilege based on CERCLA section 104(e)(7). The Hanford agreement also specifies that no party is required to provide legally privileged information. No parallel provisions appear in the LLNL or Monticello agreements.

\subsection{ARARS}

$\begin{array}{ll}\text { LLNL: } & \text { None } \\ \text { Monticel10: } & \text { Attachment } 3 \\ \text { Hanford: } & \text { Art. } 7.5 \text { (action plan) }\end{array}$

The LLNL FFA does not discuss ARARs. The Monticello agreement includes a list of federal ARARs (Attachment 3 of the FFA). Utah was to submit a proposed list of state ARARs within thirty days of execution of the agreement. The Hanford action plan contains a detailed, noninclusive list of state ARARs and identifies the EPA document "CERCLA Compliance with Other Laws Manua]" as the source for federal ARARs.

\subsection{ACCESS}

LLNL: $\quad$ Art. XVIII, pp. 41-43

Monticello: Art, XXII, PP. 56-58

Hanford: Art. XXXVII, pp. 61-63

This topic includes three distinct subtopics: 1) EPA and state access to the DOE site for oversight, 2) limits on EPA and state access to DOE documents, and 3) DOE's responsibility to obtain access to off-site property for investigation and remediation. 
The three site-specific FFAs are similar with respect to granting access to DOE sites. All three require DOE to grant EPA and the states access to the site at previously arranged, reasonable times to inspect records, operating logs, contracts and other relevant documents, to review DOE's progress, to conduct tests, and to verify data. The Hanford and Monticello FFAs condition access on presentation of proper credentials, and compliance with DOE security rules. The LLNL FFA provides that access is subject to requirements "necessary to frotect national security." The Hanford FFA reserves the right to require an escort.

All three site-specific FFAs provide some measure of protection of DOE documents from EPA and state inspection. The LLNL FFA generally conditions access by EPA and the state on "national security" requirements. In addition, Article XVIII contains LLNL's confidentiality provision, so it may be implied that it restricts access to DOE records. The Monticello FFA states that access to 'unclassified and unprivileged" documents is allowed, but does not reference its confidentiality article or otherwise define those terms. The Hanford FFA does so by referencing its Confidentiality article.

With respect to property not owned and controlled by $D 0 E$, all three sitesper:ific FFAs require DOE to use its best efforts to obtain signed access agreements, and to exercise its power under CERCLA section 104(e) relating to access, entry and information gathering. The Monticello and LLNL FFAs provide that EPA and the state "shall" lend assistance under their own authority where problems persist. The Monticello and LLNL agreements allow DOE to submit proposed modifications to the agreement in response to DOE's inability to gain access. The Hanford FFA is silent on DOE's options if it is unable to gain access. See Table 2.10 for a comparison of these provisions.

\subsection{EXTENSIONS*}

LLNL: $\quad$ Art. XIX, pp. $43-46$

Monticello: Art. XXXIII, pp. 69-71

Hanford: Art. $X L, P P .64-66$

The language in the LLNL FFA is similar to the Model Provision with the following exceptions. Requests for extensions must be made before the scheduled deadline or deliverable date. Good cause for an extension exists for delays caused by additional work agreed to by the parties. The dispute 
IABLE 2.10. Access to Property

\begin{tabular}{|c|c|c|c|}
\hline & LLNL & MONTICELLO & HANFORD \\
\hline $\begin{array}{l}\text { Conditions on } \\
\text { access to DOE } \\
\text { property by EPA/ } \\
\text { state }\end{array}$ & $\begin{array}{l}\text { "National } \\
\text { security" } \\
\text { requirements }\end{array}$ & $\begin{array}{l}\text { Presentation } \\
\text { of credentials }\end{array}$ & $\begin{array}{l}\text { Presentation of } \\
\text { credentials, safety } \\
\text { and security rules. } \\
\text { escort }\end{array}$ \\
\hline $\begin{array}{l}\text { DOE required to } \\
\text { use best efforts } \\
\text { for off-site access }\end{array}$ & Yes & Yes & Yes \\
\hline $\begin{array}{l}\text { - EPA/state } \\
\text { authority } \\
\text { available if } \\
\text { unsuccessful }\end{array}$ & Yes & Yes & No \\
\hline $\begin{array}{l}\text { - Modification of } \\
\text { agreement if } \\
\text { unsuccessful }\end{array}$ & Yes & Yes & No \\
\hline
\end{tabular}

resolution process is open to all parties rather than just DOE. The sevenday time periods in the model FFA are extended to fourteen days. A new clause is added on extension requests by EPA and state agencies.

The extension section in the Monticello agreement is adopted from the model language with the exception that the seven-day time periods are extended to fourteen days.

The Hanford agreement adopts the model language with the additional clarification that tolling of penalties is limited to stipulated CERCLA penalties.

\title{
2.22 PROGRESS REPORTS
}

\author{
LLNL: $\quad$ Attachment 2 \\ Montice 110: $\quad$ Art. XVI, P. 48 \\ Hanford: Art. XXXII, pp. 58-59
}

The LLNL FFA calis for monthly progress reports and an annual report. The Monticello FFA calls for monthly progress reports. The Hanford agreement calls for quarterly progress reports. 


\subsection{CROSSCUTTING ISSUES}

This chapter compares issues from the FFAs which are covered under a number of articles in each agreement. Accordingly, the headings in this chapter generally are subject headings rather than paralleling the articles of the FFAs.

\subsection{WORK STOPPAGES}

Model Provisions: Dispute Resolution, par. I

LLNL: $\quad$ Art. X(I), XIII, Pp. 32-33, 37-38

Monticello: $\quad$ Art. XIV(J), XVIII(D) (E), pp. 45, 50-51

Hanford: $\quad$ Art. VIII $(F), X V(J), X X I, p p .23,38,58$

The three site-specific FFAs each have two sources of stop work orders: the dispute resolution process and creation of danger or inminent hazard. Under the former they are parallel, while under the Creation of Danger sections they differ widely in the role given to DOE and the states. The three sitespecific FFAs also contain provisions for cessation of work in the event that the work is creating a danger or imminent hazard, although in Monticello's FFA it is contained in the "Project Manager" article. The three provisions are very different. Under the LLNL agreement, either EPA or the state "may request" DOE to stop work to abate any danger, but DOE "will comply . . . for any period of time determined to be appropriate by both EPA and DHS." Thus, the request appears to be mandatory. DOE also has implied authority to stop work as an "appropriate measure to protect all persons affected." Under the Monticello FFA, the EPA or DOE Project Coordinators have authority to order a cessation of work, while the state may only recommend a work stoppage to EPA. EPA's order may be verbal. DOE's order is subject to EPA review to determine if it constitutes a violation of the agreement. Only the Hanford FFA expressly gives all three parties equal authority to require a work stoppage, subject to "the appropriate" dispute resolution process at the DRC level. Therefore, depending on the operable unit involved, EPA or the state may have the final decision. The LLNL and Monticello agreements do not expressly provide dispute resolution for work stoppage decisions associated with creation of danger.

The decision as to when work can recommence can be made by either EPA or DOE under the Monticello FFA, requires concurrence of both EPA and the state under LLNL FFA, and is subject to dispute resolution under Hanford agreement. Table 3.1 presents a comparison of these provisions. 
IABLE 3.1. Work Stoppages

\section{REQUIREMENTS}

Dispute Resolution

Stop Work
- EPA can stop work during dispute resolution

- Prior consultations $w / s t a t e$ required

- Written notice to DOE required

- DOE or state can challenge decision through dispute resolution

- State or DOE may request work stoppage

LLNL MONTICELLO HANFORD MODEL

Yes

Yes

Yes

Yes

\begin{tabular}{|c|c|c|c|}
\hline No & Yes & Yes & NA \\
\hline Yes & $\begin{array}{l}\text { Yes } \\
\text { (state } \\
\text { also) }\end{array}$ & Yes & Yes \\
\hline $\begin{array}{l}\text { Yes } \\
\text { (DRC or } \\
\text { SEC) }\end{array}$ & $\begin{array}{l}\text { Yes } \\
\text { (DRC or } \\
\text { SEC) }\end{array}$ & $\begin{array}{l}\text { Yes } \\
\text { (DRC) }\end{array}$ & $\begin{array}{l}\text { Yes } \\
\text { (DRC or } \\
\text { SEC) }\end{array}$ \\
\hline
\end{tabular}

No

Yes

No

No

- State can stop work during dis-

pute over RCRA

action

Creation of Danger Stop Work

- EPA can stop work

No

NA

Yes

No

- State can stop work

$\begin{array}{llll}\text { Yes } & \text { Yes } & \text { Yes } & \text { NA } \\ \text { Yes } & \text { No } & \text { Yes } & \text { NA } \\ \text { Yes (b) } & \text { Yes (a) } & \text { Yes } & \text { NA } \\ \text { No (c) } & \text { No (c) } & \begin{array}{l}\text { Yes } \\ \text { (DRC) }\end{array} & \text { NA } \\ \text { Unclear } & \text { Yes } & \text { Unclear } & \text { NA }\end{array}$

- Verbal stop work allowed

- DOE can stop work

- Subject to dispute resolution

rar

Unclear Yes

Unclear

(a) Subject to EPA approval.

(b) Implied by DOE's authority to take "appropriate measures" to protect affected persons ( $p .37$ ).

(c) Some question as to whether general dispute resolution procedures would apply. 


\subsection{ROLE OF PROJECT MANAGERS}

Model Provisions - Review and Comment Process, par. $E$ and $F$ LLNL - Art. XVI, PP. 40-41

Monticello - Arts. XII, XVII, pp. 32, 49-53

Hanford - Art. XXXIV, Pp. 47, 59-60; Action Plan, Pp. 4 1,8-1

The role of project managers appears to be similar among the three sitespecific FFAs and within the general context established in the Model Provisions. Hanford and Monticello have three project managers, while LLNL has five.

The Hanford FFA contains several unique features concerning project managers. Each of the 74 operable units and 55 TSD groups are to have unit managers assigned. It was created because many operable units will be simultaneously studied and three project managers could not keep abreast of all work. DOE also is required to carry out RCRA TSD work under the direction and authority of Ecology. Finally, DOE is to conduct investigations and cleanup of past practice units through CERCLA and under the authority of EPA. The potential for the EPA and State to impose conflicting requirements upon DOE is recognized. See Table 3.2 for a comparison of project manager responsibilities.

TABLE 3.2. Role of Project Managers

\begin{tabular}{|c|c|c|c|c|}
\hline SUMMARY & LLNL & MONTICELLO & HANFORD & MODEL \\
\hline $\begin{array}{l}\text { Role of Project } \\
\text { Managers } \\
\text { identified }\end{array}$ & Yes & Yes & Yes & Yes \\
\hline $\begin{array}{l}\text { Number of } \\
\text { Project Managers }\end{array}$ & 5 & 3 & 3 & -- \\
\hline $\begin{array}{l}\text { Meetings among } \\
\text { Project Managers } \\
\text { (days) }\end{array}$ & 90 & 90 & 90 & 30 \\
\hline
\end{tabular}




\subsection{ACTION PLANS}

Model Provisions: None

LLNL: None

Monticello: "Work Plan"

Hanford: Action Plan

Action plans identify specific work to be taken by the responsible parties for implementing interim and or final corrective/remedial actions for site cleanup. The action plan may be included within the FFA or developed as a deliverable under the FFA. The three site-specific FFAs are significantly different in the scope and contents of their action plans. Table 3.3 presents a comparison of action $p l a n$ issues.

The LLNL FFA does not contain an action plan. It does reference a Work Plan to have been issued in November 1988. Attachment 2 to the FFA gives a general description of DOE document deliverables to reach the ROD and Remedial Design phase of CERCLA. Attachment 3 contains a single page listing these deliverables. Site environmental information is neither discussed nor cited in the FFA.

The Monticello FFA does not specifically include an action plan. Rather, it refers to a Work Plan that will include "timetables and schedules for completion of each remedial action designated in the Work Plan." The Monticello FFA and the Work Plan apply both to Vicinity Properties, where cleanup work has already begun, as well as the Millsite, where site characterization work is currently underway. The Work Plan was issued in May 1989. Based upon the existence of "functionally equivalent" CERCLA documentation, the Work Plan milestone schedule shows all RI/FS activities completed (see Work Plan Attachment entitled "Time Schedule"). The Monticello Work Plan contains no environmental data or interpretive information, but does reference pertinent documents. Though not directly noted in the FFA, plans for Monticello's Millsite remediation involve a single operable unit study executed under a single Work $\mathrm{Plan}$ with issuance of a single ROD.

The Hanford FFA contains an extensive action plan and support appendices (approximately 180 pages in length including 13 sections and 5 appendices). This plan summarizes information on some 1000 past practice units, 55 treatment, 
TABLE 3.3. Action Plans

\begin{tabular}{|c|c|c|c|c|}
\hline SUMMARY & $\underline{\mathrm{LLNL}}$ & MONT ICELLO & HANFORD & MODEL \\
\hline $\begin{array}{l}\text { Need for } \\
\text { Action Plan } \\
\text { identified }\end{array}$ & No & No & Yes & No \\
\hline $\begin{array}{l}\text { Action Plan } \\
\text { is part of } \\
\text { FFA }\end{array}$ & No & No & Yes & No \\
\hline $\begin{array}{l}\text { Need for Work } \\
\text { Plan identified }\end{array}$ & Yes & Yes & Yes & Yes \\
\hline $\begin{array}{l}\text { Action or Work } \\
\text { Plan written } \\
\text { to support FFA }\end{array}$ & Yes & Yes & Yes & -- \\
\hline $\begin{array}{l}\text { Action or } \\
\text { Work Plan } \\
\text { contains } \\
\text { detailed } \\
\text { schedules \& } \\
\text { workscopes }\end{array}$ & (a) & No & Yes & -- \\
\hline $\begin{array}{l}\text { Lead Regulatory } \\
\text { Agency clearly } \\
\text { identified }\end{array}$ & No & Yes & Yes & -- \\
\hline $\begin{array}{l}\text { Status of } \\
\text { RI/FS Activities }\end{array}$ & $\begin{array}{l}\text { Planning } \\
\text { Phase }\end{array}$ & Completed(b) & $\begin{array}{l}\text { Planning } \\
\text { Phase }\end{array}$ & -- \\
\hline $\begin{array}{l}\text { Proposed } \\
\text { completion } \\
\text { date of site } \\
\text { characterization }\end{array}$ & 1991 & Completed & 2005 & -- \\
\hline $\begin{array}{l}\text { Number of } \\
\text { Record of } \\
\text { Decisions } \\
\text { (RODs) to be } \\
\text { completed }\end{array}$ & 1 & 1 & 74 (c) & -- \\
\hline
\end{tabular}

\footnotetext{
(a) Work Plan not reviewed.

(b) Work completed under existing "functionally equivalent" documents.

(c) Final decisions regarding RCRA operable units will be documented in permit modifications.
} 
storage, and disposal (TSD) units, plus major milestones from the years 1989 through 2018 (Appendix D). The Plan also includes specific unit identifications, classifications, and work prioritizations. In addition, organizational and management responsibilities among the responsible parties are discussed. The past practice units have been divided into 74 source operable units each of which will proceed through the ROD process for site investigation and cleanup.

\subsection{INCONSISTENCY WITH ATOMIC ENERGY ACT}

LLNL: None

Monticello: Art. I, p. 3

Hanford: Art. I, pp. 4-5

The Hanford and Monticello FFAs both address the issue of possible inconsistency with the AEA while the LLNL agreement does not. Hanford's reference is contained in the Jurisdiction article and is limited to possible inconsistencies as a result of RCRA actions. Paragraph 5 states that nothing in the Hanford FFA shall be construed to require DOE to take any action pursuant to RCRA which is inconsistent with requirements of the AEA. Monticello's provision is also in the Jurisdiction article but is more general in stating that EPA will recognize DOE's responsibilities under the Atomic Energy Act. The LLNL FFA and the Model Provisions do not contain parallel provisions.

\subsection{TOPICS INCLUDED IN ONLY ONE FFA}

Several topics were included in only one of the three FFAs. The Monticello FFA includes conclusions of law (Art. VI), a section on deletion from the NPL (Art. XI), and a section on completion of reports (Art. $X$ ). The LLNL FFA includes a section on contractor recommendations (Art. $X X$ ), a separate article on the parties to the agreement (Art. VI), and an article on removal actions (Art. XIV). The Hanford agreement includes a severability clause (Art. XLIV).

The Hanford Action Plan is the only portion of any of the FFAs which directly addresses the issue of contact with other federal agencies concerning natural resources trusteeships and the conduct of health assessments. Section 7.6 of the action plan sets forth a basic framework for interacting with the National Oceanic and Atmospheric Administration and the Department of the 
Interior regarding their roles as natural resources trustees for the Hanford site.

Section 7.7 of the Hanford action plan also notes the responsibilities of the Agency for Toxic Substances and Disease Registry (ATSDR) of the U.S. Public Health Service for the conduct of health assessments. 


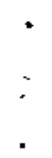


APPENDIX

TOPIC PAGE NUMBERS 


\section{APPENDIX A}

TOPIC PAGE NUMBERS

\begin{tabular}{|c|c|c|c|}
\hline TOPIC & HANFORO & $\underline{\text { LLNL }}$ & MONT ICELLO \\
\hline $\begin{array}{l}\text { Access to Administrative } \\
\text { Records }\end{array}$ & 66 & 47 & 72 \\
\hline Access to Data/Documents & 60 & 41 & 55 \\
\hline Action Plan & Attach. 2 & Attach. 3 & Work Plan \\
\hline Additional Work & 55 & 34 & 47 \\
\hline Amendment of Agreement & 63 & 54 & 63 \\
\hline ARARs & $7-19,40$ & -- & Attach. 3 \\
\hline $\begin{array}{l}\text { Classified/Confidential } \\
\text { Information }\end{array}$ & 69 & 43 & 60 \\
\hline Completion Reports & -- & -- & 25 \\
\hline Compliance with Applicable Laws & 76 & 53 & 60 \\
\hline Conclusions of Law & -- & -- & 17 \\
\hline Contractor Recommendations & -- & 46 & - \\
\hline $\begin{array}{l}\text { Covenant Not to Suel } \\
\text { Reservation of Rights }\end{array}$ & 70 & 54 & 63 \\
\hline $\begin{array}{l}\text { Creation of Danger and Reporting } \\
\text { of tnminent Health Hazard }\end{array}$ & 58 & 37 & -- \\
\hline Def'nitions & 12. App. A & 3 & 6 \\
\hline Deletion from NPL & -- & -- & 26 \\
\hline Dispute Resolution & 21,35 & 29 & 41 \\
\hline Document Classification & $9-2$ & 22 & 30 \\
\hline Enforceability & 45,24 & 58 & 65 \\
\hline Extensions & 64 & 43 & 69 \\
\hline Five Year Review & 63 & 46 & 58 \\
\hline
\end{tabular}


TOPIC

Force Majuere

Funding

Jurisdiction

Notification

Other Claims

Parties

Permits

Progress Reports

Project Managers

Property Transfer

Public Comment on Agreement

Public Participation

Purpose

Quality Assurance

RCRA/CERCLA Integration

Removal Actions

Retention of Records

Role of EPA \& State

Governments

Sampling Availability

Schedule

Severability

Scope of Agreement

Site Access
HANFORD

72

74. Attach. 3

LLNL

53

52

3

1

38

51

59

16

40

8-2

69

48

59

66

40

49

60

60

7. 1-1

55

74

49

72

57

41

53

9

16

38

60

47

56

Part 4

21

18, 27

60

41

55

Attach. 3

Action Plan

69

Exec. Sumnary 18

61

41
19

56 


\begin{tabular}{|c|c|c|c|}
\hline TOPIC & HANFORD & $\underline{L L N L}$ & MONT ICELLO \\
\hline Site Description & Exec. Summary & $\begin{array}{l}63 \\
2,4,5\end{array}$ & $\begin{array}{l}\text { Attachments 1, } \\
\text { and Work Plan }\end{array}$ \\
\hline State Recovery of Expenses & 54,43 & 49 & 61 \\
\hline $\begin{array}{l}\text { Stipulated Determinations } \\
\text { and Facts }\end{array}$ & 17,26 & 8,14 & 12,17 \\
\hline Stipulated Penalties & 43 & 56 & 66 \\
\hline Termination & 67 & 60 & 75 \\
\hline Work to be Performed & 17,29 & Attach. 2 & -- \\
\hline
\end{tabular}


PNL-7195

UC -630

\section{DISTRIBUTION}

No. of

Copies

OFFISTE

2 DOE/Office of Scientific and Technical Information

60 K.I. Tiami

U.S. Department of Energy

EH-232, 3G-092 Forrestal Building

1000 Independence Ave. S.W.

Washington, DC 20585

ONSITE

DOE Richland Operations office

R.D. Freeberg

18 Pacific Northwest Laboratory

C.A. Geffen (2)

R.E. Gephart

P.L. Hendrickson

J.F. Keller (2)

M.R. Siegel (5)

W.K. Waller

Publishing Coordination

Technical Files (5) 
• 